\title{
Natural Morality, Moral Natures and Human Flourishing
}

Darcia Narvaez,

Narvaez, D. (2014). Natural Morality, Moral Natures and Human Flourishing. In B. Musschenga \& A. van Harskamp (Eds.), Why be moral? On the capacities and conditions for being moral. [Springer Library of Ethics and Applied Philosophy] Heidelberg, Germany: Springer.

\begin{abstract}
:
I investigate natural moral values as they are empirically discoverable in human developmental psychology, and then draw moral conclusions from those values about how we ought to live, as individuals and societies. A eudaimonic ethics, focused on bringing about flourishing, necessarily involves discussion of facts and values, means and ends. The wellbeing and moral capacities of children and adults in the USA is being undermined by violations of evolved principles for early care. The dominant social structure of human genus history, small-band gatherer-hunter society, offers a useful framework for eudaimonic ethics and a possible corrective for the misdirection of modern social life.
\end{abstract}

Keywords: eudaimonia, attachment, moral development, moral emotion, moral identity, moral wisdom

Morality and moral self-knowledge have never been more important as humanity faces unprecedented challenges like ecosystem degradation and climate instability (Millenium Ecosystem Assessment, 2005; Intergovernmental Panel on Climate Change 2007). Yet human moral capacities (in the USA) seem to be diminishing. Among college students, narcissism is on the rise (Twenge and Campbell 2009) and empathy has been dropping over decades, significantly so in the last decade (Konrath et al. 2011). College student moral judgment scores are falling from an emphasis on postconventional reasoning not to conventional but down to a preference for personal interests (Thoma and Bebeau 2008). Adult misbehavior is more widespread than in the past and has become normative (Callahan 2004). Even young children are at a greater likelihood of being expelled from preschool for aggression and are increasingly being prescribed psychotropic drugs for misbehavior and dysphoria (Gillam 2005; Powell et al. 2003). These are just a few of the signals that moral functioning may be in trouble.

What is the source of these declines? A lack of moral reasoning development? Although moral reasoning offers some guidance for categorizing and constructing argumentation, and forming and formulating social agreements (Rest et al. 1999, 2000) reasoning is insufficient for instigating much moral behavior. Although individuals develop in the sophistication of their reasoning based on age, amount of education and expertise built from experience (Narvaez and Gleason 2007) and those with postconventional reasoning capacities show better clinical performance beyond intelligence in multiple professions (Rest and Narvaez 1994), the predictive power of moral judgment for moral action is weak. Some people with sophisticated reasoning capacities take moral action but many do not. 
Is it a lack of punishment? --only if you believe that humans are naturally evil and must be punished to learn be good, a Puritanical view running deeply in America's social practice, including in schools where "zero-tolerance" policies are normative (Fowler 2010). Psychological, social and anthropological sciences would certainly foment substantial global evidence against this view.

A lack of moral formation? Yes, goes the argument here. Neurobiological and psychological sciences show that the roots of individual and cultural moral expression lie in the body and in the emotions, aspects of the self that are shaped in early life (Narvaez 2008, 2010). As embodied creatures, human morality is linked to neurohormonal, emotional and other biological functioning. When these are deficient, virtue is harder to come by. Moreover, for any dynamic system, initial conditions are critical. Earlier development is built upon by later development. The source of moral difficulties may emerge from the deficient developmental environments of children whose psychobiological decrements sometimes only become apparent in adolescence or adulthood. Because humans are born extremely helpless and needy (with only $25 \%$ of the brain developed at full-term birth), their brains and bodies evolved to expect intensive responsive parenting; Trevathan 2011), the kind of care that seems to be diminishing in advanced nations, particularly in the USA.

\section{What is evolved responsive care?}

Most adults would agree that babies have needs that must be met by responsive parenting. In fact, responsiveness to the emotional needs of the child is one of the best predictors of positive child outcomes (e.g., Kochanska 2002). However, responsivity alone may not be sufficient for optimal development; additional caregiving practices may be required (Narvaez and Gleason in press).

Humans have evolved to be born extremely early to accommodate a woman's small pelvis and the child's large head (18 months early compared to other primates; Trevathan 2011). The result is that the child requires post-natal care that resembles an external womb (Montagu, 1978). The ancestral human mammalian milieu (AHMM; Narvaez and Gleason in press) represents human practices documented from extant nomadic gatherer-hunter societies (SBGH), whose lifestyle represents over $99 \%$ of human genus history (Fry 2006). Thus far scientists have focused primarily on summarizing the characteristics of early life for infants and young children among SBGH (Hewlett and Lamb 2005). See Table 1. In this chapter I also include some of the social environmental characteristics noted by anthropologists (Ingold 1999; see Narvaez in press for more). Apart from the human adaptation of multiple caregivers and variable breastfeeding length, AHMM parenting practices are over 30 million years old, having emerged with the catarrhine mammals (Konner 2010).

\section{[insert Table 1 about here]}

We can see that many of these practices hardly exist today among the majority of Western parents, especially in the USA. Does it matter? What are the consequences for abandoning evolutionarily-normative childbirth and child rearing practices? The contributors to the volume, Evolution, Early Experience and Human Development: From 
Research to Practice and Policy (Narvaez et al. in press), suggest that when these principles are violated there are lifetime consequences on health and wellbeing (see also Karr-Morse and Wiley 2012).

Early experience sets the baseline for multiple functions, psychologically, as well as physiologically. One of the constructs most studied in developmental psychology is attachment and caregiving (Ainsworth and Bowlby 1991; Bowlby 1969/1982). The attachment behavioral system is a species-universal program that bonds child to mother. It collaborates with the adult's caregiving behavioral system, which under normal conditions is a species-wide program that guides caregiving. Both programs are shaped during sensitive periods. Early life experience with caregivers sets up the attachment behavioral system in infants and young children and the caregiving behavioral system in the parent is influenced by the quality of attachment the caregiver developed during early life and other sensitive times (George and Solomon 2008). For the mother, the caregiving behavioral system is also influenced by what happens during pregnancy and birth (Trevathan 2011). Each of these species-wide programs guides the activation and selection of behaviors to reach particular goals in social relationships.

Secure attachment. When caregiving is warm and responsive, comforting the child's easily-distressed immature reflexive systems, these systems learn to maintain calm. The child learns the communicative value of interpersonal signals, both cognitive and affective, through caregiver emotional signaling - verbal communication and behavior that are synchronized, supportive and reliable. The child's needs are satisfied through the attachment figure. As a result, a secure attachment develops, accompanied by a repertoire of social communication and social behaviors appropriate for the cultural context - healthy baselines for the life to come-including the ability to self-soothe with mental representations of the caregiver.

Insecure attachment. Crittenden (1998) and Fosha (2003) describe three psychological ways in which infants adapt over time to habitual non-responsive caregivers developing forms of insecure attachment: "feeling but not dealing," "dealing but not feeling," and "neither feeling nor dealing." When the caregiver is rejecting or inconsistent, an insecure attachment develops with that caregiver. When caregivers are rejecting of a young child's overtures for affection or need satisfaction, the child learns to suppress emotion and develops an avoidant attachment (dealing but not feeling). When caregivers are inconsistent in response, the child learns to use affect as a way to get attention and needs met, shutting down cognition (since it is unreliable predictor of caregiver behavior), developing an ambivalent or anxious attachment (feeling but not dealing). When the child is abused, the child does not develop in feeling or thinking and ends up with a disorganized attachment (neither feeling nor dealing). Those with insecure attachment become inflexible and self-centered in social situations-they emotionally withdraw, attack or manipulate.

These attachment styles indicate not only the quality of the caregiver-child relationship but how well the brain works. Across animal and human studies, it is apparent that much damage to basic systems can be done in early life from perinatal trauma or poor early care (Lanius et al. 2010). The damage undermines the functioning of cell repair and development, neuronal communication and stability levels of neurotransmitters, receptors and thresholds for molecular action (Grosjean and Tsai 2007). When functioning is compromised at this level, it can be impossible to repair and 
can lead to chronic disease (Barker 1998). As a result of poor care, the brain and body are less well functioning, less physiologically integrated, and rely on systems that are minimally competent. If the body and brain can barely maintain homeostasis in the face of stress, virtue will be harder to come by. For example, self-regulation becomes a challenge when neurotransmitters run out of glucose rapidly (Galliot 2008). In fact, those with low glucose are functionally less prosocial (De Wall et al. 2010). Consequently, one may never have the sharp moral intelligence or prosocial orientation that characterizes those with good care during sensitive periods (Kochanska 2002).

Insecure attachment means that social development has gone awry for that individual (although it may be locally adaptive to avoid a rejecting parent), affecting social life for the longterm, if intervention does not ensue. Only with a brain that displays secure attachment can we be sure that moral functioning is developing in a promising direction.

Children with secure attachment live in a different moral universe from those with insecure attachment. Their brains and bodies work better from the good care received (Narvaez et al. in press). They are more socially competent and confident, friendly and trusting of others (Hazan and Shaver 1987). They are more compliant with adult wishes and are more likely to exhibit empathy, conscience, and prosocial behavior (Kochanska 2002). These are characteristics of adult moral exemplars (Walker and Frimer 2009). In contrast, children with insecure attachment are less empathic, more aggressive, and have difficulty getting along with peers (Sroufe et al 2008). Those with avoidant attachment can be emotionally distant and exhibit compulsive self-reliance (Bartholomew and Horowitz, 1991; Hazan and Shaver 198 7). In short, personalities that emerge from insecure attachment make cooperation with others difficult.

Attachment is a measurable indicator of how well early life went. However, it is a blunt indicator that does not measure the underlying physiological scars of intermittent poor care. Remember that humans are born (at full term-40-42 weeks gestation) with only $25 \%$ of the brain developed, with next to no immune system, and with all sorts of other brain and body systems to be established and interconnected. Most of this growth occurs rapidly in the first 6 years of life, co-constructed by caregivers and a built-in biological timetable that co-evolved with particular parenting practices (Trevathan 2011).

Early life experience shapes the dynamic psychosoma system that is a child. For any dynamic system, initial conditions are critical for development and later parameters of possibility. With the epigenetic revolution, we are finding out that most of who we become is formed by our experiences after conception (although the experiences of our parents and grandparents also affect our health; see Gluckman and Hanson 2005, for a review).

Here is one example of how one physiological system is shaped by early caregiving that has longterm consequences on health and wellbeing (and there are many systems that could be described). The vagus nerve is the primary nerve of the parasympathetic nervous system, the majority of whose fibers $(80 \%)$ are afferent, carrying information from the viscera to the brainstem; the other $20 \%$ of fibers are efferent, facilitating the modulation of arousal and body state, when properly developed (Porges and Carter 2010). The modulation capability is vital for social functioning, inhibiting flight or fight responses. How well the vagus functions (vagal tone) is calculated from measuring heart rate variability, a rough measure of how well the vagus 
nerve controls resting heart rate. Vagal tone function is highly affected by early-life caregiving, particularly touch (Porges 2011). The degree of variability in heart rate between breath inspiration and expiration is higher among those with good vagal tone, and is more likely to be found among those with secure attachment. Those with little variability have more difficulty handling negative emotions and socializing, as exhibited through behavioral inhibition to novel situations. Babies left to cry develop poor vagal tone and learn to employ self-protective responses in social situations. Moreover, vagal function is related to most systems in the body and when poorly functioning can lead to numerous detrimental health outcomes (digestive - e.g., irritable bowel; neuronal communication - e.g., seizures; mental health-depression; see Ghanem et al. 2006; Groves et al. 2005). The vagus nerve can even prevent inflammation, an instigator of many diseases.

Vagal tone is one of many mechanisms related to homeostatic self-control. At a very fundamental level, self-control involves mechanisms that manage stress reactivity and negative emotions. When a person's basic biology has been neglected in terms of evolved expected care in early life, he or she is set up to be stress reactive, including epigenetic effects such as not turning on genes that regulate anxiety (e.g., Meaney 2001; Weaver et al. 2002). Stress reactivity is hard to remedy later.

Physiological effects, such as stress reactivity, have moral implications. If one does not feel at ease, how can one face new people, think outside the box and socially succeed? Instead, new things (e.g., people who look or act differently) are threatening and lead to immobilized thinking, feeling, relating, or worse, reactive aggression. The contention here is that current cultural practices in the treatment of children, beginning prior to birth and throughout development, are having an influence on the health and well-being of US citizens (and similar effects may be obtained in countries that have adopted US childbirthing and childrearing practices). These practices may be undermining humanity's evolved principles for human growth and development, affecting individuals, families and societies. I believe that early life caregiving also affects a person's moral nature (Narvaez, 2008; Narvaez and Gleason 2011). Multi-ethics theory and research addresses these issues.

\section{Moral Natures and Moral development}

Multi-ethics theory (formerly called triune ethics theory, Narvaez 2008) is a descriptive psychobiological theory of moral development and moral functioning. It offers a neurobiologically based explanation for different "moral mindsets" or moral natures. An individual may learn to habitually use one mindset or another based on experience during sensitive periods. Certain situations also may evoke a particular mindset.

Three distinctive moral systems, rooted in basic brain strata that create global brain states (MacLean 1990), propel human moral action on an individual and group level: Safety, Engagement, and Imagination. Briefly, the Safety Ethic is oriented to feeling safe through following a set of conditioned prescriptions, including maintaining loyalty and purity. The Engagement Ethic is oriented to relational attunement with others, facilitating flexible empathic response. The Imagination Ethic attends to transcendent ideals and life narratives, often fueled by one of the other ethics. See Table 2 for a summary. 
[Put Table 2 about here]

The safety ethic is rooted in physiological systems for self-protection which are available at birth and shared with all animals. When an instinctive survival mindset is used in making decisions and taking action, it becomes a safety ethic. The safety ethic gets triggered by threat, physical or psychological. We all have this ethic within uswhen we are motivated to withdraw, emotionally or physically, from a relationship or lash out in self-defense. This sense of ongoing immediate threat can become a dispositional social orientation if trauma, abuse or neglect was experienced during a sensitive period in life (sensitive periods include the first five years, early adolescence, early adulthood, therapy).

When early childhood is distressful, from poor caregiving or trauma, the safety ethic can become a favored disposition when face-to-face with others. When caregiving has not provided expected companionship care (Trevarthen 2005) and a mutually responsive orientation (Kochanska 2002), individuals become distrustful and learn to structure relationships as a shift between dominance, submission and withdrawal.

There are two basic forms of safety ethic, one is proactively aggressive (bunker safety) where the individual feels enough strength and power to take action against the threat and maintain dominance. In the other mindset the individual feels too weak or paralyzed to take action and so withdraws physically and/or emotionally (wallflower safety). Dispositionally individuals can favor one or the other or flip between them depending on the situation (a bully in one situation but a doormat in another). Because self-protective mechanisms can take over the mind/brain, poor early experience that leads to stress reactivity limits genuine autonomy in the present moment. Instead, the conditioned past determines which emotions and perceptual filters are triggered and influence perceptions and action possibilities. Neuroses, as explored by Freud, demonstrate that traumatic preverbal sensory experiences can be evoked by current circumstances, leading to subjectively rational but objectively "irrational" behavior for the situation. The moral natures represented by the safety ethic are harmful to self and others in the long term.

The second moral mindset is engagement; it is about relationship, specifically, relational attunement. It draws on right brain experiencing, the awareness of energy and connection to all life that the neuroscientist, Jill Bolke Taylor (2008) described as she experienced a stroke on the left side of her brain. The Engagement Ethic focuses on connecting and bonding in the moment, on an equal basis, person to person, lifeform to lifeform. How much an individual is able to do this is based in brain systems and intuitions formed before speech, in the earliest years, and during other sensitive periods. What is occurring during relational attunement is limbic resonance (Lewis et al. 1999), or intersubjectivity with others (Trevarthen 2005). Deep engagement is required for full moral capabilities. The moral nature represented by the engagement ethic appears to match up well with the human nature exhibited by SBGH, where children are well cared for, as reported by anthropologists (Ingold 1999). In these societies, for example, individuals are cooperative and caring, value generosity and don't put up with cheating, aggression or deception. Humans share the engagement orientation with other primates but have a further moral capacity that is largely ours alone, the imagination ethic. 
The third moral mindset, the imagination ethic, is rooted in our capabilities for abstraction, or pulling away from the present moment - the calculating intelligence identified by Taylor (Taylor 2008), or what is called intellect (MacMurray 1992). Intellect, rooted in the neocortex and prefrontal cortex systems, plays a central role in imagining the future, forming and executing goals, and inhibiting and guiding action. These areas are also dependent on nurturing and can be damaged throughout life. The imagination ethic can take different forms. Ideally, it links with the prosocial orientation of the engagement ethic, becoming a communal imagination, allowing imagination to be applied to the common good. However, if it is tied up with the safety ethic, with selfprotective concerns, it becomes a vicious imagination, focused on plans for selfaggrandizement. Alternatively if one dissociates from emotions entirely, it can be a detached imagination, allowing one to create and innovate without attending to consequences. These represent different moral natures with different benefits to self and others. The SBGH appear to have a broad communal imagination, with a sense of relational responsibility to all other entities (e.g., trees, mountains, animals). They lived sustainably, for example, moving from a gathering place before they depleted the area or changing a harvested resource if it appeared distressed (Gowdy 1999).

Multi-ethics theory suggests that early experience shapes moral functioning, fostering different moral natures. That is, one's physiology and psyche built by early experience underlie one's capacities as an adult (although one is not necessarily trapped forever in the level of functioning promoted by early experience - there are other sensitive periods and one can transform oneself somewhat with extensive effort using therapy, meditation and similar practices). As noted earlier, moral capacities in the USA appear to be shrinking, emphasizing stress-reactive safety ethic, as well as vicious and detached imaginations. Current social environments in the USA foster general distrust, self-protection, self-aggrandizement, detachment from soft emotions, ultrarationalism, inability to gather empirical evidence from personal experience, and coercive and dysphoric personalities.

My laboratory has begun to study these ethics. We find that secure attachment (formed by responsive parenting) is related to prosocial personality, both of which predict having engagement ethic as a moral goal (or identity) -all of which predict moral outcomes such as helping the less fortunate (Narvaez, Brooks and Hardy 2012). Safety as a moral goal or identity is linked to insecure attachment, distrust and dishonesty. Of course it is obvious that a society will not flourish if its citizens habitually adopt safety ethics or are dispositionally detached or vicious. Such moral natures do not lead to flourishing.

\section{Human Nature and the Path to Moral Wisdom}

Pinker (2011) argues that humanity has become much more peaceful, especially in the $20^{\text {th }}$ century, due to progress in societal and institutional structures. He reaches this mistaken conclusion by ignoring prehistory and collapsing types of hunter-gatherer societies. The SBGH, representing $99 \%$ of human genus history, were largely peaceful and did not engage in war (Fry 2006). Further, Pinker narrows his definition of violence to physical aggression. The world has far more emotional and institutional violence 
today, perhaps more than ever if one counts the number of countries that are not meeting the needs of their people and the increasing undercare of children which represents forms of relational violence, from trauma at birth to thwarting of needs for breastmilk and physical closeness.

At the same time that Pinker touts human progress, he, like social moral psychology and Hobbesian evolutionary psychology today, emphasizes the selfcenteredness of humanity. Experiments are conducted to find such outcomes but also based on samples from populations raised in the aforementioned "undercaring" environments that violate evolved needs. For example, moral foundations theory (Haidt and Joseph 2007) emphasizes values that relate to safety ethic concerns (hierarchy, purity, ingroup, tit-for-tat fairness). If these are central concerns for one's morality, it reflects a deficient human nature-one that has been socialized away from the pinnacle of humanity's moral sense-communal imagination. These are not the concerns of SBGH, who were fiercely egalitarian, had porous boundaries and expected universal generosity. Instead, such self-protective concerns emerge from the degradation of social environments, especially in early life, and the downward spiral of believing in human evil, punishing children for their mammalian needs, and considering troubled outcomes to be normal rather than formed by poor environments.

Environments guide intuition development. Most of what we know and who we are resides in implicit systems that learn automatically and guide our behavior and choices most of the time (Kahneman 2011). These systems learn from whole-body experience, especially in the early years when right brain emotion networks are established from responsive care. When children are put in front of books and screens, their right brains are minimal developed and they end up with a deficient storehouse of knowledge from which to draw intuitions the rest of their lives (Schore 2003). This has moral implications. The left brain, conscious knowledge becomes the source of the moral enterprise, leading to an emphasis on detached imagination (left-brain objectivity), and then with poor early care, the use of the safety ethic in face-to-face situations.

Moral wisdom comes from understanding the nature of the world, requiring welleducated whole-brain intuitions and reliable "personal" knowledge, both of which are primarily tacit, saturated with intelligence, experience and perspective (Polanyi 1958) the opposite of left-brain emotional detachment. Whole-brain "reasoning is primarily an affair of emotion" and "none of our activities, not even the activities of thinking, can express our reason unless the emotions that produce and sustain them are rational emotions" (MacMurray 1962/1999, pp. 10-11). When we suppress and ignore emotion and emotional development, we necessarily stay in egocentric thought and cannot know the world as it is - we cannot know reality. Indeed, as mammals, emotions are central to intelligence and social functioning (Panksepp 1998). Humans with damage in emotional brain circuitry make poor decisions, including moral decisions (Damasio 1999).

The narrow, evaluative uneducated intuitions often studied in psychology experiments where novices are asked to evaluate the actions or character of someone doing something outrageous (e.g., Haidt 2001) represent the kind of evaluative activity that fits into the deficient skill level of persons who have been raised in isolation watching others act on screens--it does not comprise moral behavior, which of course is much more complicated. This type of veridical decision making is relatively easy and can use the primitive systems of decision making that underlie the safety ethic. The real work 
of decision making, including moral decision making, is adaptive decision making--what is required in the real world where nothing is prepackaged, when one has to figure out how to sort out the stimuli and figure out what is going on, what might be done, what role one might take, and so on and so forth. This is the real work of moral functioning and it can be called moral imagination.

Moral imagination is a sophisticated type of deliberation. As Dewey says, it includes "the capacity to concretely perceive what is before us in light of what could be" (Dewey in Fesmire 2003, p. 2). It works with thought experiments, through the dramatic rehearsal of alternative courses of action and possible outcomes. This form of internalized social action requires tacit knowledge that includes the wisdom of emotion and the understanding of the nature of the world. Moral imagination allows humans the "ability to choose ends and goals," ends that, unlike for other animals, are not dictated by simple biology. Humans also have the ability to calculate the means to reach their goals (Neiman 2008, pp. 189, 191). Moral imagination involves a variety of higher order thinking skills considered to be key factors in astute thinking (Perkins 1995), such as the ability to decenter away from one's current view and to generate alternative scenarios and look for counterevidence to first reactions, impulses, and preconclusions.

Real life social experience builds the storehouse of knowledge from which moral wisdom can emerge. The more practiced and refined one's imagination is, the richer the bank of possibilities and the more reliable one's evaluations are (Dewey 1922/2000). But what Dewey may not have understood is that early life experience is critical for the bank of knowledge from which one draws examples and intuitions about imagined possibilities. Fluency in generating alternative viewpoints, particularly the perspective of others, is a skill that develops not only from prefrontal cortex development, highly influenced in the first years of life and fully mature by the third decade of life (Goldberg 2002), but also through life experience generally and within particular domains (Feshbach 1989; Selman 2003).

Deliberation generally facilitates "self-authorship" (Baxter Magolda 2001). When we feel a sense of injustice or upset, we can step back from the response and ask whether it is an appropriate response and whether it is a reliable guide for action (Sen 2009).

School-based programs in social and emotional learning are documented to help students stop the rapid emotional response and think more carefully about action (e.g., Elias et al. 2008) and increase cognitive competencies in decision making (see Catalano et al. 2008, for a review), allowing the individual to monitor intuitions. Reason allows us to select the environments that "tune up" our intuitions (Hogarth 2001), a means to self-cultivate virtue. But babies and young children cannot select their environments, despite their critical importance for long term outcomes. Adults must take on the responsibility for ensuring that babies and young children are provided their basic needs. Human capacities and human nature are both better represented by the moral personalities of small-band hunter-gatherer groups where children are well cared for and adults behave virtuously as a matter of course (Ingold 1999).

If we take human flourishing and virtue as aims of development, then the SBGH social context offers a framework for both the aims and the means. See Table 3. The means include meeting the needs of babies and young children fully, when bodies, brains and personalities are being formed. Humans evolved for intense social community and become depressed and psychotic in isolation, much like Harlow's (Harlow et al. 1965) 
monkeys. But this social embeddness does not mean coercive conformity. Individuals have autonomy from a young age and even adults could choose to go on hunts or gathering trips (Ingold, 1999). Social activities such as singing, dancing, joking, make communal life very enjoyable and attractive. The SBGH have a good sense about human egos and what can cause problems, so they were "fiercely egalitarian," discouraging any boasting or self-aggrandizement. Principles of generosity and sharing were implicit, along with expulsion for aggression, coercion or deception. The social lifestyle from birth and early childhood through adulthood represents a moral fabric or flow of experience that facilitates virtue, including ecological virtue.

\section{[Put Table 3 about here]}

Should we be worried about the naturalistic fallacy? Some might accuse me of mixing fact and value, making ethical prescriptions based on descriptions of natural facts. This is a misunderstanding. As several philosophers have pointed out (e.g., MacIntyre 1959), the naturalistic fallacy is a false problem. As Owen Flanagan (2009) notes, Hume (1739) was warning readers to beware of clerics who made is-to-ought prescriptions, exhibiting deductive logical errors. Flanagan (2012) emphasizes that ethics represents a "biopsychosocial technology involving sensible determination of ends and means." I adopt Flanagan's (2012) view that "eudaimonics is a descriptive-normative theory of the causes and constituents of human flourishing, including ethics." As Murdoch (1989) points out, philosophy should be addressing eudaimonic questions, such as 'how do we make ourselves morally better?' That is the aim here.

\section{The future is the past}

One might argue that the USA has learned to value and nurture the wrong things. With its emphasis on reason and scientific detachment instead of appreciative presence common among SBGH (Narvaez 2012), the USA has larded up self-protective and detached thinking, starving deep relational attunement and engagement. USA personalities generally are inadequate for facing humanity's moral problems today or for bringing about wellbeing across life forms. Somehow we have forgotten that the good life requires well-cultivated emotion. Humans apprehend life with emotional-cognitive capacities. How well these are developed by early experience influence subsequent socialization into a culture and by chosen experiences throughout life.

Through childrearing practices that violate the evolved practices described earlier and through other practices like sensory-deadening schooling, the USA may be fostering a misshapen morality, one that doesn't live up to human potential. By misguiding emotional development in early life (through the use of punishment, neglect of children's needs), it seems to have emphasized a narrow intelligence, a left-brain dominant version of functioning (McGilchrist 2009). This seems to be exemplified in the USA in that EQ (emotional intelligence) has been decreasing while "IQ" scores have been rising throughout the $20^{\text {th }}$ century. But IQ scores have risen only because of increased scores on subtests representing abstract thinking, the ability to emotionally detach and answer hypothetical questions (i.e., scientific thinking; Flynn 2007). Thus IQ represents mere "intellect," a narrow type of knowledge based in conscious, linear thinking, that current 
childrearing and schooling practices seem to emphasize. Schooling smothers emotion development, emphasizing left-brain detached thinking, not wisdom of any kind.

\section{Conclusion}

Current moral psychology findings are misleading. Human nature is not so selfish, except that we have adopted a culture that shapes us this way (speaking of the USA has). The range of psychopathology has been made enormously wide due to miscultivation of children. As Turnbull (1973) noted, the evisceration of human emotion development leaves children empty by adolescence. It leaves them vulnerable to the ideologies of their surround, whether the Protestant work ethic, religious fundamentalism, or the hot ideology today, egoism. In contrast, wholistic knowledge encompasses welltrained emotions and intuitions built from coached experience, starting from responsive caregiving at birth. Infants expect companionship care and are ready for mutual responsive communication (Trevarthen 2005) — which builds a fully social and intelligent brain. In the societies of our $99 \%$, morality was integral to survival and was deep in personality and a relational psychology (see Narvaez in press, for more). I agree with MacMurray that the key element of morality is the capacity for empathic, joyful coordination of a web of personal relationships, a personal emotional wisdom that one can apply to more complex problems. It involves small egos, the ability to give and take in playful interaction, a type of ego-detachment that allows one to truly see reality without purpose except to give full attention (Murdoch 1989). Moral wisdom emerges from this immersion in deep, extensive engagement with others.

\section{References}

Ainsworth MDS, Bowlby J (1991) An ethological approach to personality development. Am Psych 46 333-341

Barker DJ (1998) In utero programming of chronic disease. Clin Sci 95: 115-128

Bartholomew K, Horowitz LM (1991) Attachment styles among young adults: A test of a four-category model. J Pers Soc Psy 61: 226-244

Baxter Magolda MB (2001) Making their own way: Narratives for transforming higher education to promote self-development. Sterling VA, Stylus

Bowlby J (1969/1982) Attachment and loss: Vol 1 Attachment (2 ${ }^{\text {nd }}$ ed) Basic Books, New York (Original work published 1969)

Bystrova K, Ivanova V, Edhborg M, Matthiesen AS, Ransjö-Arvidson AB, Mukhamedrakhimov R, Uvnäs-Moberg K, Widström AM (2009) Early contact versus separation: effects on mother-infant interaction one year later. Birth 36(2): 97-109

Callahan D (2004) The cheating culture: Why more Americans are doing wrong to get ahead. Harcourt Harvest, New York NY 
Catalano RF, Hawkins JD, Toumbourou JW (2008) Positive youth development in the united states: History efficacy and links to moral and character education In: Nucci LP and Narvaez D (eds) Handbook of moral and character education. Routledge, New York, pp 459-483

Crittenden PM (1995) Attachment and psychopathology. In: Goldberg S Muir R and Kerr J (eds) Attachment theory: Social developmental and clinical perspectives. The Analytic Press, Hillsdale NJ, pp 367-406

Crittenden PM (1998) The developmental consequences of childhood sexual abuse. In: P Trickett P, Schellenback D (eds) Violence against children in the family and the community. American Psychological Association, Washington DC, pp 11-38

Damasio A (1999) The feeling of what happens. Heineman, London

Dawson G, Ashman SB, Carver LJ (2000) The role of early experience in shaping behavioral and brain development and its implications for social policy. Dev Psychopath 12: $695-712$

DeWall CN, Pond RS, Bushman BJ (2010) Sweet revenge: Diabetic status as a predictor of interpersonal forgiveness. Pers Ind Diff 49: 823-826

Dewey J (2000) Human nature and conduct: An introduction to social psychology. Prometheus, New York (Original work published 1922)

Elias MJ, Parker SJ, Kash VM, Weissberg RP, O’Brien MU (2008) Social and emotional learning moral education and character education: A comparative analysis and a view toward convergence. In: Nucci LP D Narvaez D (eds) Handbook of moral and character education. Routledge, New York, pp 248-266

Ersche et al (2012) Abnormal brain structure implicated in stimulant drug addiction. Sci 3335(6068): 601-604

Feshbach ND (1989) Empathy training and prosocial behavior In: Grobel J, Hinde RA (eds) Aggression and war: Their biological and social bases. Cambridge University Press, Cambridge United Kingdom, pp 101-111

Fesmire S (2003) John Dewey and the moral imagination: Pragmatism in ethics. Indiana University Press, Bloomington

Flanagan O (2012) What do the psychology and biology of morality have to do with ethics? Etics as human ecology. Presentation at The Evolution of Morality: The Biology and Philosophy of Human Conscience Erice Sicily, June 17-22 
Flanagan O (2009) The really hard problem: Meaning in a material world. MIT Press, Cambridge, MA

Flynn JR (2007) What is intelligence? Cambridge University Press, New York

Fosha D (2003) Dyadic regulation and experiential work with emotion and relatedness in trauma and disorganized attachment. In: Solomon M Siegel D (eds) Healing trauma: Attachment mind body and brain. Norton, New York, pp 221-281

Fowler D (2010) Texas' school-to-prison pipeline: Ticketing arrest \& use of force in schools-- How the myth of the "blackboard jungle"reshaped school disciplinary policy. Texas Appleseed, Austin TX

Fry D P (2006) The human potential for peace: An anthropological challenge to assumptions about war and violence. Oxford University Press, New York

Galliot MT (2008) Unlocking the energy dynamics of executive functioning: Linking executive functioning to brain glycogen. Persp on Psych Sci 3(4): 245-263

George C, Solomon J (2008) The caregiving system: A behavioral system's approach to parenting. In: Cassidy J, Shaver P (eds) Handbook of attachment: Theory research and clinical applications. Guilford, New York, pp 833-856

Ghanem T, Early S (2006) Vagal nerve stimulator implantation: An otolaryngologist's perspective. Otolaryng - Head Neck Surg 135 (1): 46-51 doi:101016/jotohns200602037 PMID 16815181

Gilliam WS (2005) Prekindergarteners left behind: Expulsion rates in state prekindergarten systems. Yale University Child study Center, New Haven CT

Gluckman P, Hanson M (2005) Fetal Matrix: Evolution development and disease. Cambridge University Press, New York

Goldberg E (2002) The Executive brain: Frontal lobes and the civilized brain. Oxford University Press, New York

Gowdy J (1999) Gatherer-hunters and the mythology of the market In: Lee RB, Daly R (eds) The Cambridge encyclopedia of hunters and gatherers. Cambridge University Press, New York, pp 391-398

Grosjean B, Tsai GE (2007) NMDA neurotransmission as a critical mediator of borderline personality disorder. J Psych Neurosci 32(2): 103-115 
Groves DA, Brown VJ (2005) Vagal nerve stimulation: A review of its applications and potential mechanisms that mediate its clinical effects. Neurosci Biobeh Rev 29 (3): 493 doi: 101016/jneubiorev200501004

Haidt J (2001) The emotional dog and its rational tail: A social intuitionist approach to moral judgment. Psych Rev 8: 814-34

Haidt J, Joseph C (2007) The moral mind: How 5 sets of innate intuitions guide the development of many culture-specific virtues and perhaps even modules In: Carruthers $\mathrm{P}$, Laurence S, Stich S (eds) The Innate Mind Vol 3 Oxford University Press, New York, pp 367-391

Harlow HF, Dodsworth RO, Harlow MK. (1965) Total social isolation in monkeys. Proc Natl Acad Sci U S A. 54(1): 90-97

Hazan C, Shaver P (1987) Romantic love conceptualized as an attachment process. JPSP 52(3): 511-524

Hewlett BS, Lamb ME (2005) Hunter-gatherer childhoods: Evolutionary developmental and cultural perspectives. Aldine, New Brunswick NJ

Hogarth R M (2001) Educating Intuition. University of Chicago Press, Chicago

Hume D (1739) A treatise of human nature. John Noon, London

Ingold T (1999) On the social relations of the hunter-gatherer band. In: Lee RB, Daly R (eds) The Cambridge encyclopedia of hunters and gatherers. Cambridge University Press, New York, pp 399-410

Intergovernmental Panel on Climate Change (2007) Climate change 2007: A synthesis report. World Meteorological Organization (WMO) and United Nations Environment Programme (UNEP), Geneva Switzerland

Kahneman D (2011) Thinking fast and slow. Farrar Strauss \& Giroux, New York

Karr-Morse R, Wiley MS (2012) Scared sick: The role of childhood trauma in adult disease Basic Books, New York

Kochanska G (2002) Mutually responsive orientation between mothers and their young children: A context for the early development of conscience. Curr Dir Psy Sci 11(6): 191195 doi:101111/1467-872100198

Konner M (2010) The Evolution of childhood. Belknap Press, Cambridge MA

Konrath S, O’Brien EH, Hsing C (2011) Changes in dispositional empathy over time in college students: A meta-analysis. Pers Soc Psych Rev 15: 180-198 
Lanius RA, Vermetten E, Pain C (Eds) (2010) The impact of early life trauma on health and disease: The hidden epidemic. Cambridge University Press, New York

Lewis T, Amini F, Lannon R (2000) A general theory of love. Vintage, New York

MacIntyre AC (1959) Hume on "Is" and "Ought." Phil Rev 68(4): 451-468

MacLean PD (1990) The Triune Brain in Evolution: Role in Paleocerebral Functions. Plenum, New York

MacMurray J (1992) Reason and emotion, Humanity Books, Amherst NY

McGilchrist I (2009) The master and his emissary: The divided brain and the making of the western world. Yale University Press, New Haven CT

Meaney MJ (2001) Maternal care gene expression and the transmission of individual differences in stress reactivity across generations. Ann Rev Neurosci 24: 1161 -1192

Millennium Ecosystem Assessment (2005) Ecosystems and Human Well-being. Washington DC, Synthesis Island Press

Montagu A (1978) Learning nonaggression: The experience of non-literate societies. Oxford University Press, New York

Murdoch I (1989) The sovereignty of good. Routledge, New York [First published in 1970]

Narvaez D (2008) Triune ethics: The neurobiological roots of our multiple moralities. New Ideas Psy 26: 95-119

Narvaez D (2010) Moral complexity: The fatal attraction of truthiness and the importance of mature moral functioning. Persp Psych Sci 5(2): 163-181

Narvaez D (in press) Development and socialization within an evolutionary context: Growing Up to Become "A good and useful human being." In: Fry D (ed) War, peace and human nature: The convergence of evolutionary and cultural views. Oxford University Press, New York

Narvaez D (in press) Neurobiology and moral mindsets In: Heinrichs K, Oser F (eds) Moral and Immoral Behavior: Theoretical and Empirical Perspectives on Moral Motivation. Sense Publishers, Rotterdam

Narvaez D, Brooks J, Hardy S (2012) A Multidimensional Approach to Moral Identity: Early Life Experience Prosocial Personality and Moral Outcomes. (Manuscript submitted for publication) 
Narvaez D, Gleason T (2007) The Influence of moral judgment development and moral experience on comprehension of moral narratives and expository texts. J Gen Psych 168(3): 251-276

Narvaez D, Gleason T (in press) Developmental optimization In: Narvaez D, Panksepp J, Schore A, Gleason T (eds) Evolution early experience and human development: From research to practice and policy. Oxford University Press, New York

Narvaez D, Panksepp J, Schore A, Gleason T (Eds) (in press) Evolution early experience and human development: From research to practice and policy. Oxford University Press, New York

Neiman N (2008) Moral clarity: A guide for grown-up idealists. Harcourt, New York

Panksepp J (1998) Affective neuroscience: The foundations of human and animal emotions. Oxford University Press, New York

Perkins D (1995) Outsmarting IQ: The emerging science of learnable intelligence. Free Press, New York

Pinker S (2011) The better angels of our nature. Viking, New York

Polanyi M (1958) Personal knowledge: Towards a post-critical philosophy. University of Chicago Press, Chicago

Porges S W (2011) The polyvagal theory: Neurophsiologial foundations of emotions attachment communication self-regulation. WW Norton, New York

Powell D, Fixen D, Dunlop G (2003) Pathways to service utilization: A synthesis of evidence relevant to young children with challenging behavior. Center for Evidencebased Practice: Young Children with Challenging Behavior, University of South Florida FL

Rest, JR, Narvaez D (eds) (1994) Moral development in the professions: Psychology and applied ethics. Lawrence Erlbaum, Hillsdale, NJ

Rest JR, Narvaez D, Bebeau MJ, Thoma SJ (1999) Postconventional moral thinking: A neo-Kohlbergian approach, Erlbaum, Mahwah NJ

Rest JR, Narvaez D, Bebeau M, Thoma S (2000) A neo-Kohlbergian approach to morality research. J Mor Ed 29: 381-395

Schore A (2003a) Affect regulation and the repair of the self. Norton, New York Schore A (2003b) Affect dysregulation and disorders of the self. Norton, New York 
Selman RL (2003) The promotion of social awareness: Powerful lessons from the partnership of developmental theory and classroom practice. Russell Sage, New York

Sen A (2009) The idea of justice. Harvard University Press, Cambridge MA

Trevathan WR (2011) Human birth: An evolutionary perspective, $2^{\text {nd }}$ edn. Aldine de Gruyter, New York

Taylor JB (2008) My stroke of insight. Viking, New York

Trevarthen C (2005) Action and emotion in development of the human self its sociability and cultural intelligence: Why infants have feelings like ours. In: Nadel J, Muir D (eds) Emotional Development. Oxford University Press, Oxford, England, pp 61-91

Turnbull CM (1983) The human cycle. Simon and Schuster, New York

Twenge J, Campbell R (2009) The narcissism epidemic: Living in the age of entitlement. Free Press, New York

Thoma S J, Bebeau M (2008) Moral judgment competency is declining over time: Evidence from 20 years of defining issues test data. Paper presented to the American Educational Research Association New York

Weaver IC, Szyf M, Meaney MJ (2002) From maternal care to gene expression: DNA methylation and the maternal programming of stress responses. Endocr Res 28: 699

Walker LJ, Frimer JA (2009) Moral personality exemplified. In: Narvaez D, Lapsley DK (eds) Personality identity and character: Explorations in moral psychology. Cambridge University Press, New York NY, pp 232-255 
Table 1. Ancestral Human Mammalian Milieu For Babies and Young Children

NATURAL CHILDBIRTH (no interference with timing, no drugs, no separation of mom and baby)

BREASTFEEDING: Nursed frequently (2-3 times/hr initially) for 2-5 years (average weaning at 4 years)

TOUCH: Held or kept near others constantly

RESPONSE: Prompt responses to fusses and cries

EXTENSIVE MATERNAL SUPPORT and ALLOPARENTS: Shared care by adults other than mothers; extensive social embeddedness of mother-child dyad

PLAY: Enjoy free play in natural world with multiage playmates

POSITIVE SOCIAL CLIMATE AND POSITIVE EMOTIONS: Daily life filled with laughter, singing, dancing

Table 2. Types of Moral Mindsets

\begin{tabular}{|l|l|l|l|l|l|l|}
\hline Type & $\begin{array}{l}\text { Bunker } \\
\text { Safety }\end{array}$ & $\begin{array}{l}\text { Wallflower } \\
\text { Safety }\end{array}$ & Engagement & $\begin{array}{l}\text { Communal } \\
\text { Imagination }\end{array}$ & $\begin{array}{l}\text { Detached } \\
\text { Imagination }\end{array}$ & $\begin{array}{l}\text { Vicious } \\
\text { Imagination }\end{array}$ \\
\hline Focus & \multicolumn{2}{|l|}{ Self-protection } & $\begin{array}{l}\text { Harmony or } \\
\text { Relational } \\
\text { attunement }\end{array}$ & $\begin{array}{l}\text { Egalitarian } \\
\text { social problem } \\
\text { solving }\end{array}$ & $\begin{array}{l}\text { Manipulation } \\
\text { and control }\end{array}$ & $\begin{array}{l}\text { Dominance } \\
\text { or revenge }\end{array}$ \\
\hline $\begin{array}{l}\text { Response } \\
\text { to stress }\end{array}$ & $\begin{array}{l}\text { Fight, } \\
\text { Flight }\end{array}$ & Freeze & $\begin{array}{l}\text { Tend and } \\
\text { befriend }\end{array}$ & $\begin{array}{l}\text { Higher } \\
\text { consciousness }\end{array}$ & Disassociation & $\begin{array}{l}\text { Hostility, } \\
\text { Control }\end{array}$ \\
\hline
\end{tabular}

Table 3. Comparison of Social Life in Small-Band Gatherer-Hunter Communities and $21^{\text {st }}$ Century USA

\begin{tabular}{|c|c|c|}
\hline Topic & SBGH Social Life & $21^{\text {st }}$ century USA Social Life \\
\hline Maternal support & Complete & Undermining of mothers \\
\hline Babies and children & Needs fully met & Minimal support \\
\hline Child behavior & No coercion & Coercion and punishment \\
\hline Autonomy & Individuals do what they want & $\begin{array}{l}\text { Limited mostly to consumer } \\
\text { choices }\end{array}$ \\
\hline Community & $\begin{array}{l}\text { High commitment and } \\
\text { cooperation }\end{array}$ & Minimal connection to others \\
\hline Source of pleasure & Social activities & $\begin{array}{l}\text { Individual activities (television, } \\
\text { internet) }\end{array}$ \\
\hline Virtues & $\begin{array}{l}\text { Communal generosity and } \\
\text { sharing expected }\end{array}$ & Self-interest \\
\hline Vices & $\begin{array}{l}\text { Cheating, deception, } \\
\text { aggression not tolerated }\end{array}$ & $\begin{array}{l}\text { Cheating, deception, aggression } \\
\text { expected }\end{array}$ \\
\hline Relation to natural & Partnership; treatment of & Nature objectified, manipulated; \\
\hline
\end{tabular}


\begin{tabular}{|l|l|}
\hline world & other entities as subjects not
\end{tabular} objects; deep connection to Life everything else assumed to serve humanity's aims; little awareness of Life 